\title{
POWER GENERATION AND GASEOUS EMISSIONS PERFORMANCE OF AN INTERNAL COMBUSTION ENGINE FED WITH BLENDS OF SOYBEAN AND BEEF TALLOW BIODIESEL
}

\begin{abstract}
Waldir Nagel Schirmer ${ }^{1}$, Mayara Ananda Gauer ${ }^{2}$, Edson Tomaz ${ }^{3}$, Paulo Rogério Pinto Rodrigues $^{4}$, Samuel Nelson Melegari de Souza ${ }^{5}$, Luiz Inácio Chaves ${ }^{6}$, Lucas Villetti ${ }^{7}$, Luciano Zart Olanyk ${ }^{8}$, Alexandre Rodrigues Cabral ${ }^{9, *}$
\end{abstract}

1 Environmental Engineering Department, Universidade Estadual do Centro-oeste (UNICENTRO), Irati, Brazil. Address: PR 153 Road, Km 07, Riozinho Square, Irati, Parana State, Brazil, Zip code 84.500-000. Phone: 55 (42) 34213216. wanasch@hotmail.com

2 Environmental Engineering Department, Fundação Municipal Centro Universitário da Cidade de União da Vitória, Bento Munhoz da Rocha Neto Avenue, 3856, São Basílio Magno Square, União da Vitória, Parana State, Brazil, Zip Code 84600-000. Phone: +55 42 3522-1837. E-mail: mayaragauer@yahoo.com.br

${ }^{3}$ Chemical Processes Department, Chemical Engineering Faculty, Universidade Estadual de Campinas (UNICAMP), Albert Einstein Avenue, 500, Barão Geraldo Square, Campinas, São Paulo State, Brazil, Zip code 13083-852. Phone: +55 19 3521-3953. E-mail: etomaz@feq.unicamp.br

${ }^{4}$ Chemistry Department, Universidade Estadual do Centro-oeste (UNICENTRO), Camargo Varela de Sá Street, 03, Vila Carli Square, Guarapuava, Parana State, Brazil, Zip Code 85040-080. Phone: +55 42 3629-8100. E-mail: prprodrigues@gmail.com

5 Center of Exact and Technological Sciences, Universidade do Oeste do Paraná, Universitária Street, 2069, Universitário Square, Cascavel, Parana State, Brazil, Zip code 85814-110. Phone: +55 45 3220-7438. E-mail: melegsouza@hotmail.com

${ }^{6}$ Instituto Federal do Paraná - Campus Assis Chateaubriand, Cívica Avenue, 475, Centro Cívico Square, Assis Chateaubriand, Parana State, Brazil, Zip code 85935-000. Phone: +55 44 3528-0800. E-mail: luizinaciochaves@yahoo.com.br

7 Center of Exact and Technological Sciences, Universidade do Oeste do Paraná, Universitária Street, 2069, Universitário Square, Cascavel, Parana State, Brazil. Phone: +55 45 3220-7438. E-mail: E-mail: lucasvilletti@yahoo.com.br

Schirmer, W.N., Gauer, M.A., Tomaz, E., Rodrigues, P.R.P., de Souza, S.N.M., Chaves, L.I., Villetti, L., Olanyk, L.Z. and Cabral, A.R. (2016). Power generation and gaseous emissions performance of an internal combustion engine fed with blends of soybean and beef tallow biodiesel. Environmental Technology, 37 (12): 1480-1489. DOI: 10.1080/09593330.2015.1119202 
8 Mechanical Engineering Department, Universidade Tecnológica Federal do Paraná (UTFPR), Sete de Setembro Avenue, 3165, Curitiba, Parana State, Brazil, Zip code 80.230901. Phone: 55 (42) 34231259 E-mail: lzrt@hotmail.com

9 Dept. Civil Engineering, Université de Sherbrooke, Sherbrooke, QC, Canada J1K 2R1; +1 819-821-7906; alexandre.cabral@usherbrooke.ca.

* Corresponding Author 


\section{Abstract}

3 This study aimed to compare the performance of an internal combustion engine fed with

4 blends of biodiesel produced from soybean and diesel, and blends of biodiesel produced from

5 beef tallow and diesel. Performance was evaluated in terms of power generated at low

6 loading conditions $(0.5 ; 1.0$ and $1.5 \mathrm{~kW})$ and emission of organic and inorganic pollutants. In

7 order to analyze inorganic gases $\left(\mathrm{CO}, \mathrm{SO}_{2}\right.$ and $\left.\mathrm{NO}_{\mathrm{x}}\right)$, an automatic analyzer was used and the

8 organic emissions (BTEX) were carried out using a Gas Chromatograph (GC). The results

9 indicate that the introduction of the two biodiesels in the fuel caused a reduction in $\mathrm{CO}, \mathrm{SO}_{2}$

10 and BTEX emissions. In addition, the reduction was proportional to the increase in loading

11 regime. Beef tallow biodiesels presented better results regarding emission than soybean

12 biodiesels. The use of pure biodiesels also presented a net reduction in pollutant gas

13 emissions without hindering the engine generator performance.

15 Key-words: air pollution; biodiesel; diesel; gas emissions; volatile organic compounds. 


\section{Introduction}

18 The development of alternative - and cleaner - sources of energy has become a major

19 preoccupation of researchers and businesses alike. In particular, the use of biodiesel as an

20 energy source is becoming a viable and environmentally friendly alternative to diesel.

21 Several studies reported in the literature suggest the environmental advantages of using

22 biodiesel - pure or in blends with diesel - for internal combustion engines. A study carried

23 out by the U.S. EPA [1], estimated that the use of a blend with $20 \%$ soybean-generated

24 biodiesel and $80 \%$ diesel leads to a reduction of $\sim 10 \%$ in particulate material, $\sim 21 \%$ in

25 hydrocarbons and $11 \%$ in carbon monoxide emissions, but a $2 \%$ increase in $\mathrm{NO}_{\mathrm{x}}$ emissions.

26 Ferreira et al. [2] analyzed the volatile organic compound (VOC) emissions in compression

27 ignition engines fueled with diesel and a blend of diesel and biodiesel (B10). In their study,

28 an indirect-injection, four-cylinder engine, coupled with a hydraulic dynamometer, was used

29 with a maximum power generation of $50 \mathrm{~kW}$. The engine worked for 30 hours under varying

30 torques and at a constant rotation $(2500 \mathrm{rpm})$. The results showed a reduction in benzene

$31(19.5 \%)$ and ethylbenzene (4.2\%) emission with the use of B10, in comparison to pure diesel

32 emissions. Corrêa and Arbilla [3] tested mamona ethyl-derived biodiesel in a six-cylinder

33 diesel engine, at $1500 \mathrm{rpm}$ rotation and steady-state. They obtained a reduction in

34 monoaromatic and polyaromatic hydrocarbon emissions when biodiesel was added to the fuel

35 mix. Dorado et al. [4] carried out tests with pure waste olive oil methyl ester-derived

36 biodiesel and diesel in indirect injection engines operating under steady-state. In this

37 situation, it was verified that the use of biodiesel led to a reduction in $\mathrm{CO}(\sim 59 \%) ; \mathrm{CO}_{2}$

$38(\sim 9 \%)$; $\mathrm{NO}(\sim 37 \%)$ and $\mathrm{SO}_{2}(\sim 58 \%)$ emissions. However, the introduction of these types of 
39 biodiesel caused an $81 \%$ increase in $\mathrm{NO}_{2}$ emissions and $8.5 \%$ increase in fuel consumption.

40 In addition, the technical literature in this particular field seems to corroborate the statement

41 that biodiesel combustion emissions are directly dependent on raw-material precursor and

42 engine operation conditions, such as load and power.

44 The purpose of this study was to evaluate the emissions of inorganic $\left(\mathrm{CO}, \mathrm{NO}_{\mathrm{x}}\right.$ and $\left.\mathrm{SO}_{2}\right)$, and

45 organic (benzene, toluene, ethylzenbene and xylene - BTEX) pollutants, as well as the

46 energetic performance of an internal combustion engine operating under low loadings. Due to

47 their toxicity and harmful effects to human health even in low concentrations, the organic

48 compounds chosen for quantification were benzene, toluene, ethylbenzene and xylenes

49 (BTEX) [5]. They are mainly released by vehicles and are amongst the most commonly

50 found volatiles in the urban atmosphere [5-7]. They are considered as precursors of

51 photochemical reactions that occur in the lower atmosphere, contributing to the formation of

52 photochemical smog [8].

54 The fuels used were blends of soybean biodiesel and mineral diesel, and blends of the latter

55 with beef tallow biodiesel and mineral diesel. Several volumetric blending proportions with

56 mineral diesel were used (B0, B5, B20, B50 and B100). Beef tallow and soybean are by far

57 the main precursors of biodiesels in Brazil, corresponding to $\sim 92 \%$ of the biodiesel

58 production in the country [9].

60 A great number of studies involving biofuels are restricted to their possible use as a substitute

61 for gasoline and diesel, and how the latter two compare with biofuels in terms of energy 
62 output. Quite often, environmental aspects associated with fuel use, such as quantities of

63 greenhouse emissions, are not considered. This aspect is considered herein and is one

64 important novelty of the study.

\section{2. Material and methods}

71 In order to carry out the tests in a bench engine, pure type A diesel (provided by Petrobras

72 S.A., Brazil) was used. It had a maximum sulfur content of $1800 \mathrm{ppm}$ and was exempt of any

73 additives. The two basic biodiesel fuels, soybean methyl ester biofuel (herein identified as

$74 \mathrm{SB}$ ) and beef tallow biofuel (herein identified as BT), were obtained from companies

75 registered at the Petroleum Natural Gas and Biofuels National Agency (ANP, Brazil). BT is a

76 mix of beef tallow methyl ester (62\%) and soybean methyl ester (38\%). The BT composition

77 results from regulatory requirements that state that soybean must be added to beef tallow so

78 that BT meets the ANP requirements [10] to be commercialized as fuel [11].

80 The upper heating value (UHV) was determined in the laboratory for the three fuels and their

81 blends. The lower heating value (LHV) for each fuel and composition tested was estimated

82 according to Penido Filho [12]. Blends were prepared with 0, 5, 20, 50 and 100\% vol. of each

83 biodiesel in the diesel. These proportions are represented herein by B0, B5, B20, B50 and 
84 B100. Formulation B5 was required by Brazilian legislation when the experiments were

85 performed [13]. As of 2015, the required proportion is $7 \%$.

86

872.2 Characterization of the engine used and performance tests

89 Emission and power-generation performance tests were performed with a direct-injection, 90 monophase power generator (Branco, model BD $6500 \mathrm{CF}$ ) yielding $7.36 \mathrm{~kW}$ of power

91 coupled with a $5.5 \mathrm{~kW}$ load panel. For each diesel-biodiesel proportion (SB0 to SB100 and

92 BT0 to BT100), the following loadings were evaluated: $0.5 \mathrm{~kW}, 1.0 \mathrm{~kW}$ and $1.5 \mathrm{~kW}$,

93 corresponding to approximately $10 \%, 20 \%$ and $30 \%$ of the total load supported by the load

94 panel $(5.5 \mathrm{~kW})$. It is worth noting that the manufacturer claims that this Branco model can be

95 powered by alternative fuels (such as biodiesel).

96

97 Engine performance evaluations were carried out for each blend of fuel. The first step was to

98 calculate the brake specific fuel consumption (BSFC; $\mathrm{g} / \mathrm{kWh}$ ) using mass consumption data

$99 \quad(\mathrm{~kg} / \mathrm{s})$ and applying Eq. (1):

100

$101 \quad B S F C=3600 M C / V i$

102

103 where $\mathrm{V}$ is the output voltage (V) and $\mathrm{i}$ is the electrical current (A)

104

105 Finally, the overall performance, expressed as overall efficiency as a function of the system

106 load (E; \%), was calculated using Eq. (2) [14]: 
$108 \quad \mathrm{E}=\frac{3600}{\mathrm{LHV} \mathrm{BSFC}} \times 100$

109

110 All the necessary parameters were collected in duplicate and the statistical analysis used was

111 the Randomized Experimental Block Design (Tukey test, at 5\% probability level).

112

1132.3 Combustion emission tests

114

115 2.3.1 Inorganic gases

116 An automatic combustion gas analyzer (Bacharach, model PCA3-285KIT / 24-8453) was

117 used to monitor the emissions of $\mathrm{CO}, \mathrm{NO}_{\mathrm{x}}\left(\mathrm{NO}+\mathrm{NO}_{2}\right)$ and $\mathrm{SO}_{2}$, which are typically released

118 by diesel cycle vehicles. The equipment probe was located near the exhaust gas outlet (or

119 pipe), transversally to the combustion gas exhaust flow. For each sampling, the analyzer was

120 brought to equilibrium with the environmental conditions until the oxygen measurement

121 leveled back to $20.9 \%$ vol. at atmospheric pressure. Inorganic gas emissions were assessed

122 for loads $0.5,1.0$, and $1.5 \mathrm{~kW}$, using the same number of fuel formulations previously

123 described. More than 50 samples were collected for $\mathrm{CO}$ analysis and 30 for $\mathrm{SO}_{2}$ and $\mathrm{NO}_{\mathrm{x}}$ for

124 each fuel blend. Statistical analyses were performed following the Randomized Experimental

125 Block Design Test (Tukey test, at 5\% probability level).

126

127 2.3.2 Organic gases

128 Sampling and analyses 
129 Organic emission tests were carried out for all fuel blends and power loadings. Organic gas

130 sampling followed the U.S. EPA Compendium Method TO-17 [15]. The VOC present in the

131 air were collected by active sampling onto 89-mm long, 6-mm OD and 4-mm ID Perkin

132 Elmer glass sorbent tubes. The solid adsorbent used was the $60-80 \mathrm{mesh}, 35-\mathrm{m}^{2} / \mathrm{g}$ specific

133 surface area porous polymer Tenax TA (2,6-diphenyl-p-phenylene oxide; supplied by

134 Supelco). The sorbent tubes were filled with $180 \mathrm{mg}$ Tenax TA and conditioned in automatic

135 thermal desorption for 30 minutes at $320{ }^{\circ} \mathrm{C}$. This ensured the removal of any artifact that

136 could be present in the adsorbent bed. The choice for this adsorbent took into account its

137 hydrophilic feature, minimum artifact level $(<1 \mathrm{ng})$ [15]. In addition, this absorbent is

138 designed to be used in thermal desorption system equipment. The adopted desorption

139 parameters are presented in Table 1.

141 Pumping air into the tubes was carried out with a portable pump (AirChek, XR 5000) with 142 sampling air flow fixed at $100 \mathrm{~mL} / \mathrm{min}$. It was, therefore, possible to adjust the sampling 143 volume according to the safe sampling volume [15]. Sampling and preliminary analyses 144 pointed out that the safe sampling volume for organic gases was $500 \mathrm{~mL}$.

146 After sampling, the tubes were wrapped in tin foil and sent for analysis to the Environmental

147 Technology Development Research Laboratory at the Chemistry Engineering College of

148 Campinas State University (UNICAMP). Samples were analyzed using a Perkin Elmer gas

149 chromatograph, model AutoSystem XL, equipped with a flame ionization detector (FID). 
152 Table 1 Desorption parameters in automatic thermal desorption (ATD)

155 In order to separate the compounds, a $60-\mathrm{m}$ long capillary column, $100 \%$ dimethyl

156 polysiloxane, was used. The chromatographic conditions adopted in this study are presented

157 in Table 2. The FID operational conditions were the following: temperature $-250{ }^{\circ} \mathrm{C}$;

158 synthetic air flow $-420 \mathrm{~mL} / \mathrm{min}$; hydrogen flow $-45 \mathrm{~mL} / \mathrm{min}$.

161 Table 2 Chromatographic oven heating conditions

\section{Quality control and calibration curves for organic gases}

165 For quality control, organic emission tests included duplicate samplings (for all fuel blends

166 and power loadings) and field blanks. Two tubes were used as field blanks, submitted to the

167 same conditioning, storage and transport conditions as the tubes used in the analyses [15].

168 The detection and quantification limits (DL and QL) were estimated from the analytical

169 response of laboratory blanks. The standard deviation of mass obtained in the blanks was

170 multiplied by 3.3 to estimate the DL and by 10 to estimate the QL [16].

172 BTEX were quantified by external standard calibration. To prepare the solutions for the 173 calibration curves, methanol (Merck $K G a A$ ) was used as a solvent. The stock solution 174 preparation requires previous knowledge of the mass band of the substances that will be 
175 sampled. A six-point calibration curve (all points in triplicate) for each BTEX was performed

176 so that these analytical curves covered a wide range of masses for the analytes in the samples.

177 In all cases, the coefficients of determination $\left(\mathrm{R}^{2}\right)$ were greater than 0.99 .

178

179 The concentration of each BTEX compound was determined considering its mass (as

180 determined by chromatography) and the safe sampling volume used to trap the gas (500 $\mathrm{mL})$.

181 The retention times, detection and quantification limits for each BTEX are shown in Table 3.

182

183 Table 3 BTEX retention times, detection and quantification limits.

\section{Results and discussion}

\subsection{Engine generator performance}

189

190 The results obtained from engine performance parameters are presented in Table 4. A first

191 important observation that can be drawn from the results is that mass consumption values

192 were not statistically different from one another (at a 5\% probability level), regardless of the 193 applied load and fuel blend. 
196 Table 4 - Mass consumption (Mc), brake specific fuel consumption (BSFC) and overall

197 efficiency as a function of the system load (E) using diesel, biodiesel and their blends (at a

$1985 \%$ probability level) ${ }^{\mathrm{a}}$

200 The results presented in Fig. 1 show that brake specific fuel consumption (BSFC) is not 201 affected by variations in fuel blends, a pattern also observed by Oberweis and Al202 Shemmeri[17] in their comparison of diesel, biodiesel and blends of the two. However, the 203 increase in load supplied to the engine caused a statistically significant reduction in BSFC.

204 Similar results were found by Silva et al. [14] when testing diesel and waste fat biodiesel in 205 an engine generator identical to the one used in this study. Silva et al. [14] claim that the 206 BSFC tends to be higher in low load situations (particularly when lower than $1.5 \mathrm{~kW}$ ). 207 Valente et al. [18] also observed that the BSFC tends to decrease with higher loads. 208 According to Heywood [19], the increase in BSFC at lower loads is associated with low 209 speeds, which cause lower inertial stress and reduce the mechanical efficiency. The latter is 210 due to higher efforts to pump the gases inside and outside the combustion chamber, and to 211 friction forces from mobile parts inside the engine. In addition to the preceding, Heywood 212 [19] observed that when loads are increased, fuel mass consumption tends to increase due to 213 the higher effort required. This higher amount of burnt fuel, supplies more energy inside the 214 combustion chamber and, as a consequence, causes the temperature to increase. As a result, 215 fuel is burned more efficiently because any residual that would be released with the exhaust 216 gases, gets burned. Accordingly, despite the increase in fuel mass consumption, a reduction 217 in BSFC with higher loads is observed due a more efficient thermodynamic use of the fuel 218 [19]. 
220 Fig. 1 Brake specific fuel consumption (BSFC) as a function of fuel type, fuel blends and 221 loads.

223 In Fig. 2, it can be observed that the tendency of the overall efficiency (E) was to increase for

224 all types of blends, with higher efficiencies obtained when higher loadings were supplied to 225 the engine. In addition, the overall efficiency increased with increasing content of biofuel in 226 the mix. For SB, the gain in efficiency with increasing biofuel addition was marginal for the 227 lower loads $(0.5$ and $1.0 \mathrm{~kW}$; in fact there was a slight decrease for SB5). On the other hand, 228 for the higher load $(1.5 \mathrm{~kW})$, the value of E actually decreased for soybean biofuels, but 229 bounced up for the pure biofuel (SB100). The latter's overall efficiency was nearly $15 \%$ 230 greater than that of B0 (14.4\% from $12.7 \%)$. For BT, the general tendency was for E to 231 increase with increasing loads and blends, with the exception of BT5 at $0.5 \mathrm{~kW}$ and BT20 at $2321.5 \mathrm{~kW}$. The maximum performance obtained in this study was $14.4 \%$, for pure soybean 233 diesel (SB100) at $1.5 \mathrm{~kW}$ load. The tendencies observed corroborate those obtained by Silva

234 et al. [14], who also reached the conclusion that for loads lower than $1.5 \mathrm{~kW}$, engine 235 performances remained lower than $15 \%$.

237 Fig. 2. Overall efficiency (E) as a function of system load and fuel type and blends.

2393.2 Inorganic gas emissions - $\mathrm{CO}, \mathrm{SO}_{2}$ and $\mathrm{NO}_{x}$ 
241 The concentrations of inorganic gas $\left(\mathrm{CO}, \mathrm{SO}_{2}\right.$ and $\left.\mathrm{NO}_{\mathrm{x}}\right)$ emitted for each load, fuel type and

242 blend are presented in Table 5. To simplify the interpretation of these results, they are also

243 presented in graphic form in Fig. 3.

245 Table 5 Inorganic gas emissions (average values and standard deviation at a 5\% probability

$246 \quad$ level $)^{\mathrm{a}}$

248 Fig. 3. Inorganic gas emissions as a function of load, fuel type and blend.

250 Fig. 3a shows that $\mathrm{CO}$ emissions increased with small additions of biofuel to mineral diesel,

251 regardless of the load applied. However, when biofuel additions became greater than $50 \%$,

252 CO emissions decreased abruptly and significantly. Beef tallow biodiesel led to greater

253 decreases in $\mathrm{CO}$ emissions than soybean biodiesel. These results were similar to those

254 presented by U.S. EPA [1] which concluded that animal fat biodiesel, due to its higher level

255 of molecule saturation, led to greater reductions in CO emissions than the soybean biodiesel.

257 Reductions in $\mathrm{CO}$ emissions were higher in conditions in which higher load was applied to 258 the engine. This tendency was also observed by Bueno[20], who evaluated CO combustion 259 emissions in an engine fueled with diesel and 20\% soybean ethyl ester (B20), working at 260 constant speed $(2000 \mathrm{rpm})$ and under load fractions 33,66 and $100 \%$ of maximum torque. In 261 general, the $\mathrm{CO}$ emissions presented herein corroborate those found in the technical literature $262[4,21-23]$. 
264 The percentage of oxygen measured (Table 5) was lower for blends with low biofuel 265 additions (SB5, BT5, SB20 and BT20), which is associated with the greater CO emissions 266 observed for these blends (Fig. 3a). As more biofuel is added to mineral diesel, the

267 concentrations of emitted $\mathrm{O}_{2}$ increase and those of $\mathrm{CO}$ become lower. Schumacher et al. [24]

268 and Wang et al. [25] explained that the presence of oxygen in biodiesel provides better

269 conditions for complete combustion, leading to a reduction in $\mathrm{CO}$ emissions. In addition, 270 biodiesels have higher cetane numbers, which facilitates complete combustion (as it promotes

271 reduction in ignition delay) and, consequently leads to lower CO release [26, 27].

273 For SB5, the results showed a slight increase in $\mathrm{SO}_{2}$ emissions at higher loads, while the 274 emissions at the lowest load remained the same. For beef tallow, however, $\mathrm{SO}_{2}$ emissions 275 remained at almost the same level for the lower loads after an addition of $5 \%$ of this biofuel, 276 but decreased by nearly $25 \%$ when the higher load ( $1.5 \mathrm{~kW})$ was applied.

278 For blends with more than $20 \%$ of the two biofuels, the trend in $\mathrm{SO}_{2}$ emissions was quite 279 similar to that observed for $\mathrm{CO}$, i.e. a continuous decrease in emissions with further addition 280 of the biofuels. BT emissions for all loads - and blends with more than $20 \%$ of biofuels 281 were lower than those of SB, except when pure biodiesel was employed. The fact that BT 282 blends generate fewer $\mathrm{SO}_{2}$ emissions, agrees with the findings of a study by Miller [28], who 283 observed that the emissions level of this pollutant are lower with animal fat biodiesel, when 284 compared to soybean biodiesel. 
286 In the end, $\mathrm{SO}_{2}$ emissions from each of the pure biofuels were approximately $75 \%$ lower than

287 those from pure diesel (B0). Miranda[29] reached similar results employing waste cooking

288 oil biodiesel. Reductions found for this pollutant are justified by the fact that the biodiesel is

289 practically sulfur free $[27,30-32]$ compared to $1800 \mathrm{ppm}$ commonly found in diesel.

$291 \mathrm{NO}_{\mathrm{x}}$ emissions showed a very different pattern when compared to the other two pollutants

292 discussed above. The emissions of this pollutant remarkably increased with increasing loads

293 applied to the engine, a behavior also observed by Cheung et al.[33], Elango and

294 Senthilkumar [34], and Xue et al. [35]. However, considering each load separately, there is

295 no apparent pattern associated with $\mathrm{NO}_{\mathrm{x}}$ emissions as the amount of biofuel in the mix

296 increases. A greater database might help identify a clearer response of the system to the

297 increase in biofuel addition.

299 Nabi et al. [21] pointed out that the highest oxygen content in biodiesel [due to a higher

300 concentration of oxygenated groups, such as esters] and proper adjustment of fuel injection

301 timing can contribute to the increase in $\mathrm{NO}$ and $\mathrm{NO}_{2}$ emissions. Other studies (i.e. Oberweis

302 and Al-Shemmeri [17]) claim that the increase in $\mathrm{NO}_{\mathrm{x}}$ emissions with the increase in load,

303 results from the higher temperatures reached in the combustion chamber (and $\mathrm{NO}_{\mathrm{x}}$ emissions

304 are directly related to the gas combustion temperature). In the present study, the increases in

305 temperature (data not presented) from the low to the mid loadings are minimum, whereas the

306 increases from the mid to the high load vary between $5^{\circ} \mathrm{C}$ and $10^{\circ} \mathrm{C}$ (by all means, not a 307 steep increase). 
$309 \mathrm{Li}$ and Gülder [36] claim that the increase in the biodiesel cetane number might be

310 responsible for a reduction in $\mathrm{NO}_{\mathrm{x}}$ emissions under low loading conditions. Considering that

311 the loads employed in this study were $10 \%, 20 \%$ and $30 \%$ of the maximum load, the previous

312 statement seems to corroborate the findings of the present study.

313

3143.3 Organic Gas Emissions - BTEX

315

316 BTEX Determination

317 The average concentrations obtained as a function of the engine load and fuel used, for the

318 four compounds, are illustrated in Figures 4 to 7 . Analyses of the field blanks prepared for

319 each blend and loading did not show the presence of any of the BTEX compounds within 320 detectable limits.

321

322 Fig. 4. Benzene emissions with different fuels and loads evaluated.

324 Fig. 5. Toluene emissions with different fuels and loads evaluated.

326 Fig. 6. Ethylbenzene emissions with different fuels and loads evaluated.

328 Fig. 7. Xylene emissions with different fuels and loads evaluated.

330 The general pattern for all four compounds was clearly of decreasing emissions with

331 increasing addition of both biofuels. However, the magnitude and intensity of the decrease in 
332 emissions varied depending on the type of compound and loading applied. Table 6

333 summarizes the changes in BTEX concentrations for all blends and loads.

335 Table 6 BTEX emissions relative to pure diesel (SB0 or BT0)

337 One of the most common arguments in the literature to explain the BTEX emission 338 reductions when biodiesel is used as a substitute for diesel is the higher oxygen content and 339 cetane number of biodiesels. The fact that biodiesels are more oxygenated than pure diesel

340 favors their oxidation, therefore leading to lower emissions of these pollutants. A higher 341 cetane number favors combustion and promotes lower ignition delay, which reduces

342 incomplete burning, and, consequently, emission of these hydrocarbons [37, 38].

344 Soybean presented higher BTEX concentrations than beef tallow for all comparable blends 345 and loadings. This possibly results from the higher cetane index of methyl esters originated 346 from the beef tallow biodiesel, which possess a higher degree of molecule saturation [27, 39].

347 The lowest emissions were found when pure beef tallow (BT100) was used. SB100 produced 348 lower BTEX emissions than those of pure diesel, except in the case of Benzene, for which

349 SB100-associated emissions were higher when the lower and higher loadings were applied.

350 The higher oxygen content of pure biodiesel - as compared to pure diesel - also explains why

351 these compounds are more easily oxidized, and, as a result, their use leads to lower emission 352 values than pure diesel [23]. 
354 In the case of benzene, there was a reduction in emissions with increasing loads applied to

355 the engine (Fig. 4) for blends containing 50\% of the two biofuels (i.e. SB50 and BT50). This

356 fact was also reported by Di et al. [38] and Cheung et al. [33] and can be attributed to the

357 higher temperatures reached inside the combustion chamber at higher loads, which facilitates

358 thermal oxidation of benzene. For BT100, there was a slight increase in emissions from the

359 lower loading to the intermediate one (Fig. 4).

360

361 Ballesteros et al. [40], who tested the response of a diesel engine when biodiesels were

362 employed, observed that the only monoaromatic detected in exhaust, for blends with over

$36370 \%$ of biofuels, was benzene.

364

365 As far as Toluene emissions are concerned, only the SB50 blend (for all loadings) did not

366 follow the general pattern of decreasing emissions with addition of SB biofuel to pure diesel.

368 An addition of $50 \%$ soybean biofuel to pure diesel led to an increase in ethylbenzene

369 emissions for the intermediate and higher loadings. Otherwise, the general pattern of

370 decreasing emissions with addition of biofuel and increase in loading observed for this

371 compound, corroborate what was found in several studies, including one by the U.S. EPA

372 [1], which concluded that ethylbenzene emission reductions could be greater than $61 \%$ when

373 biodiesel is used as a substitute for diesel. In another study, Miranda [29] found that

374 ethylbenzene emissions were approximately $75 \%$ lower when biodiesel was used, while

375 Magara-Gomez et al. [41] obtained nearly no ethylbenzene emissions when using soybean

376 biodiesel and beef tallow biodiesel in a farm tractor. 
378 Finally, as far as xylenes are concerned, the increase in emissions associated with SB50 was

379 only noticeable for the intermediate and higher loadings (1.0 and $1.5 \mathrm{~kW})$, although much

380 less steep than observed for the other compounds. Several other studies observed a clear

381 reduction in xylene emissions when biodiesels were added to pure diesel [1, 33, 38, 41].

383 According to Corrêa and Arbilla [3], in order to explain emission variations with the addition

384 of biodiesel to diesel, it is necessary to analyze in detail the engineering of the engine

385 generator employed, as well as the degradation mechanisms of organic compounds at high

386 combustion temperatures (thermodynamic destruction, direct emission through incomplete

387 combustion and pyrosynthesis). The same authors also highlighted that the diesel cycle

388 engine combustion is a complex process influenced by several factors such as liquid

389 atomization, quantity of air in the mixture and burning at high temperatures and pressures.

390 The addition of biodiesel to diesel might alter some of the latter's physico-chemical

391 properties and this might result in greater or lower amounts of substances released to the 392 atmosphere.

\section{Conclusions}

397 The present study involved two precursors of biodiesel, namely soybean and beef tallow.

398 Together, they are responsible for approximately $92 \%$ of biodiesel production in Brazil. The 
results permit to conclude that the use of the two selected biodiesels is advantageous with

400 respect to performance and combustion emissions for the engine generator tested.

401

402 A first important observation that can be drawn from the study is that mass consumption 403 values did not vary significantly, regardless of the biofuel, applied load and fuel blend. Brake

404 specific fuel consumption is not affected by variations in fuel blends for both types of 405 biofuels. The tendency of the overall efficiency was to increase for all types of blends when 406 higher loadings were supplied to the engine. In addition, the overall efficiency increased with 407 increasing content of biofuel in the mix.

409 As far as emissions abatement is concerned, reductions were in fact obtained, but their 410 magnitude - or importance - varied according to the contaminant studied and to the 411 operational conditions. Indeed, there were reductions in $\mathrm{CO}, \mathrm{SO}_{2}$ and $\mathrm{BTEX}$ emissions with 412 the use of biodiesel. Beef tallow biodiesel led to greater decreases in $\mathrm{CO}$ emissions than 413 soybean biodiesel. The same applied to $\mathrm{SO}_{2}$ reductions, except when pure biodiesel was 414 employed. In the latter case, emissions from the pure biodiesels were approximately the 415 same. This situation was expected, considering that these fuels are basically aromatic and 416 sulfur free in their composition. Use of beef tallow biodiesel led to lower emissions than 417 those produced by soybean biodiesel. NOx emissions showed a very different pattern when 418 compared to the other two pollutants with emissions notably increasing with increasing loads.

419 No particular pattern in NOx emissions reduction or increase as a function of mix increase 420 was observed. 
422 It should be pointed out that the best performance and emission reductions for the engine

423 generator tested occurred when each of the two biodiesels used were blends containing

424 greater than $50 \%$ of the two biofuels. Therefore, considering the methodology followed in

425 this study, the use of the current proportion of biodiesel addition to diesel in Brazil (7\%) does

426 not present an optimal environmental advantage.

\section{Acknowledgements}

430

431 The Authors would like to thank the Conselho Nacional de Desenvolvimento Científico e 432 Tecnológico (CNPq, Brazil) for its financial support and the Laboratory of Environmental 433 Technologies Research and Development (LPDTA - UNICAMP) for its technical support. 


\section{References}

[1] USEPA (2002). A Comprehensive Analysis of Biodiesel Impacts on Exhaust Emissions, Report EPA420-P-02-001, National Vehicle and Fuel Emissions Laboratory, Ann Arbor, MI, $126 \mathrm{p}$.

[2] Ferreira, S.L., et al. (2008). Analysis of the emissions of volatile organic compounds from the compression ignition engine fueled by diesel-biodiesel blend and diesel oil using gas chromatography. Energy, 33(12): 1801-6.

[3] Corrêa, S.M. and G. Arbilla (2006). Aromatic hydrocarbon emissions in diesel and biodiesel exhaust. Atmospheric Environment, 40(35): 6821-6826.

[4] Dorado, M.P., et al. (2003). Exhaust emissions from a diesel engine fueled with transesterified waste olive oil. Fuel, 82(11): 1311-1315.

[5] Buczynska, A.J., et al. (2009). Atmospheric BTEX-concentrations in an area with intensive street traffic. Atmospheric Environment, 43(2): 311-318.

[6] Fernandes, M.B., et al. (2002). Atmospheric BTX and polyaromatic hydrocarbons in Rio de Janeiro, Brazil. Chemosphere, 47(4): 417-425.

[7] Ras-Mallorqui, M.R., R.M. Marce-Recasens, and F. Borrull-Ballarin (2007). Determination of volatile organic compounds in urban and industrial air from Tarragona by thermal desorption and gas chromatography-mass spectrometry. Talanta, 72(3): 941950.

[8] Muezzinoglu, A., M. Odabasi, and L. Onat (2001). Volatile organic compounds in the air of Izmir, Turkey. Atmospheric Environment, 35(4): 753-760. 
[9] Agência Nacional do Petróleo, Gás Natural e Biocombustíveis (ANP). Boletim Mensal de Biodiesel, November 2013, Brasília - DF, 14 p.

[10] Agência Nacional do Petróleo, Gás Natural e Biocombustíveis (ANP). Resolução No. 14, May 2012, Brasilia, 9 p.

[11] Corrêa, I.M., J.V.G. Maziero, and M. Storino (2011). Mistura de biodiesel de sebo bovino em motor diesel durante 600 horas. Ciência Rural, 41(7): 1189-1194.

[12] Penido Filho, P., Os motores à combustão interna. $1^{\text {st }}$ ed. Vol. 1. 1983, Belo Horizonte: Ed. Lemi. 699 p.

[13] Ministério de Minas e Energia (MME). C.N.d.P. Energética. Resolução no 06, Art. 2o, Lei no 11.097/2005, 2009, Brasília, Brazil.

[14] Silva, M.J., et al. (2012). Motor gerador ciclo diesel sob cinco proporções de diesel com óleo diesel. Revista Brasileira Engenharia Agrícola e Ambiental, 16(3): 320-326.

[15] USEPA (1999). Determination of Volatile Organic Compounds in Ambient Air Using Active Sampling Onto Sorbent Tubes, Compendium of Methods for the Determination of Toxic Organic Compounds in Ambient Air (TO-17), $2^{\text {nd }}$ ed., Report EPA/625/R-96/010b, USEPA, Cincinnati, OH, $53 \mathrm{p}$.

[16] Ribani, M., C.H. Collins, and C.B.G. Bottoli (2007). Validation of chromatographic methods: Evaluation of detection and quantification limits in the determination of impurities in omeprazole. Journal of Chromatography A, 1156(1-2): 201-205.

[17] Oberweis, S. and T.T. Al-Shemmeri (2010). Effect of Biodiesel blending on emissions and efficiency in a stationary diesel engine. in $10^{\text {th }}$ Intl. Conf. on Renewable Energies and Power Quality, (Ed.), Granada, Spain, 23-25 March 2010, CD-Rom, Paper 314. 
[18] Valente, O.S., et al. (2010). Fuel consumption and emissions from a diesel power generator fuelled with castor oil and soybean biodiesel. Fuel, 89(12): 3637-3642.

[19] Heywood, J.B., Internal combustion engine fundamentals. 1988, New York: McGraw Hill. 930 p.

[20] Bueno, A.V. (2006). Análise da operação de motores diesel com misturas parciais de biodiesel. Ph.D. Thesis, Faculdade de Engenharia Mecânica, Universidade Estadual de Campinas; $120 \mathrm{p}$.

[21] Nabi, M.N., M.M. Rahman, and M.S. Akhter (2009). Biodiesel from cotton seed oil and its effect on engine performance and exhaust emissions. Applied Thermal Engineering, 29(11-12): 2265-2270.

[22] Pereira, R.G., et al. (2007). Exhaust emissions and electric energy generation in a stationary engine using blends of diesel and soybean biodiesel. Renewable Energy, 32(14): 2453-2460.

[23] Qi, D.H., et al. (2009). Combustion and performance evaluation of a diesel engine fueled with biodiesel produced from soybean crude oil. Renewable Energy, 34(12): 27062713.

[24] Schumacher, L.G., et al. (1996). Heavy-duty engine exhaust emission tests using methyl ester soybean oil/diesel fuel blends. Bioresource Technology, 57(1): 31-36.

[25] Wang, W.G., et al. (2000). Emissions from nine heavy trucks fueled by diesel and biodiesel blend without engine modification. Environmental Science and Technology, 34(6): 933-939.

[26] Altiparmak, D., et al. (2007). Alternative fuel properties of tall oil fatty acid methyl ester-diesel fuel blends. Bioresource Technology, 98(2): 241-246. 
[27] Knothe, G., et al., Manual do Biodiesel. 2006, São Paulo: Edgard-Blücherp.

[28] Miller, C.A. (2008). Characterizing Emissions from the Combustion of Biofuels, Report EPA/600/R-08/069, U.S. Environmental Protection Agency, National Risk Management Research Laboratory, Research Triangle Park, NC, 51 p.

[29] Miranda, G.R. (2007). Avaliação das Emissões Atmosféricas Provenientes da Combustão do Diesel, Biodiesel de Óleo de Fritura e suas Misturas. M.Sc. Thesis, Universidade Federal de Santa Catarina; 108 p.

[30] Agarwal, A.K. (2006). Biofuels (alcohols and biodiesel) applications as fuels for internal combustion engines. Prog. Energy Combust. Sci., 33: 233-271.

[31] Tashtoush, G.M., M.I. Al-Widyan, and M.M. Al-Jarrah (2004). Experimental study on evaluation and optimization of conversion of waste animal fat into biodiesel. Energy Conversion and Management, 45(17): 2697-2711.

[32] Villarreyes, J.A.M., et al. (2007). Diesel/biodiesel proportion for by-compression ignition engines. Fuel, 86: 1977-1982.

[33] Cheung, C.S., L. Zhu, and Z. Huang (2009). Regulated and unregulated emissions from a diesel engine fueled with biodiesel and biodiesel blended with methanol. Atmos. Environ., 43: 4865-4872.

[34] Elango, T. and T. Senthilkumar (2011). Combustion and emission characteristics of a diesel engine fuelled with jatropha and diesel oil blends. Therm. Sci., 15(04): $1205-1214$.

[35] Xue, J., T.E. Grift, and A.C. Hansen (2011). Effect of biodiesel on engine performances and emissions. Renew. Sust. Energ. Rev., 15: 1098-1116. 
[36] Li, X. and Ö. Gülder, L., Effects of fuel cetane number, density and aromatic content on diesel engine NOx emissions at different operating conditions, in $4^{\text {th }}$ International Symposium Comodia. 1998: Kyoto, Japan. p. 111-116.

[37] Lim, Y., et al. (2012). The Effect of the Diesel Cetane Number on Exhaust Emissions Characteristics by Various Additives. J. Therm. Sci. Techn., 7(01): 90-103.

[38] Di, Y., C.S. Cheung, and Z. Huang (2009). Experimental investigation on regulated and unregulated emissions of a diesel engine fueled with ultra-low sulfur diesel fuel blended with biodiesel from waste cooking oil. Sci. Total Environ., 407: 835-846.

[39] Dabdoub, M.J., J.L. Bronzel, and M.A. Rampin (2009). Biodiesel: Visão Crítica do Status Atual e Perspectivas na Academia e na Indústria. Revista Química Nova, 32(03): 776-792.

[40] Ballesteros, R., et al. (2008). Speciation of the semivolatile hydrocarbon engine emissions from sunflower biodiesel. Fuel, 87(10-11): 1835-1843.

[41] Magara-Gomez, K.T., et al. (2012). Sensitivity of hazardous air pollutant emissions to the combustion of blends of petroleum diesel and biodiesel fuel. Atmos. Environ., 50: 307-313. 
List of Tables

Table 1 Desorption parameters in automatic thermal desorption (ATD)

Table 2 Chromatographic oven heating conditions

Table 3 BTEX retention times, detection and quantification limits.

Table 4 - Mass consumption (Mc), brake specific fuel consumption (BSFC) and overall efficiency as a function of the system load (E) using diesel, biodiesel and their blends (at a $5 \%$ probability $\left.^{\text {level}}\right)^{\text {a }}$

Table 5 Inorganic gas emissions (average values and standard deviation at a 5\% probability level) $)^{\mathrm{a}}$

Table 6 BTEX emissions relative to pure diesel (SB0 or BT0) 


\section{List of Figures}

Fig. 1 Brake specific fuel consumption (BSFC) as a function of fuel type, fuel blends and loads.

Fig. 2. Overall efficiency (E) as a function of system load and fuel type and blends.

Fig. 3. Inorganic gas emissions as a function of load, fuel type and blend.

Fig. 4. Benzene emissions with different fuels and loads evaluated.

Fig. 5. Toluene emissions with different fuels and loads evaluated.

Fig. 6. Ethylbenzene emissions with different fuels and loads evaluated.

Fig. 7. Xylene emissions with different fuels and loads evaluated. 
Table 1. Desorption parameters in automatic thermal desorption (ATD)

Parameter

\begin{tabular}{cc} 
Parameter & ATD operation condition \\
\hline Valve temperature $\left({ }^{\circ} \mathrm{C}\right)$ & 205 \\
Tube temperature $\left({ }^{\circ} \mathrm{C}\right)$ & 300 \\
Trap high $\left({ }^{\circ} \mathrm{C}\right)$ & 300 \\
Trap low $\left({ }^{\circ} \mathrm{C}\right)$ & -30 \\
Transfer line $\left({ }^{\circ} \mathrm{C}\right)$ & 205 \\
Desorption time $(\mathrm{min})$ & 15 \\
Desorption flow $(\mathrm{mL} / \mathrm{min})$ & 60 \\
Column flow $(\mathrm{mL} / \mathrm{min})$ & 1 \\
Inletsplit $(\mathrm{mL} / \mathrm{min})$ & 45 \\
Outletsplit $(\mathrm{mL} / \mathrm{min})$ & 25 \\
Pressure $(\mathrm{psi})$ & 20 \\
Carrier gas & $\mathrm{He}$ \\
\hline
\end{tabular}


Table 2. Chromatographic oven heating conditions

\begin{tabular}{cccc}
\hline Step & Rate $\left({ }^{\circ} \mathrm{C} / \mathrm{min}\right)$ & Temperature $\left({ }^{\circ} \mathrm{C}\right)$ & Time $(\min )$ \\
\hline Initial & 0.0 & 35 & 35 \\
1 & 2.0 & 60 & 10 \\
2 & 1.5 & 80 & 5 \\
3 & 7.0 & 100 & 10 \\
\hline
\end{tabular}

Table 3. BTEX retention times, detection and quantification limits.

\begin{tabular}{cccc}
\hline Pollutant & Retention time (min) & Detection limit (ng) & Quantification limit (ng) \\
\hline Benzene & 12.82 & 2.43 & 8.10 \\
Toluene & 22.10 & 11.67 & 38.91 \\
Ethylbenzene & 33.30 & 3.22 & 10.74 \\
$m . p$-Xylenes & 35.87 & 0.06 & 0.20 \\
$o$-Xylene & 38.51 & 0.19 & 0.64 \\
\hline
\end{tabular}




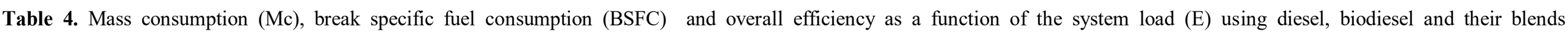
(at $5 \%$ probability level) ${ }^{\mathrm{a}}$

\begin{tabular}{|c|c|c|c|c|c|c|c|c|c|c|c|}
\hline \multirow{2}{*}{ Parameters } & \multirow{2}{*}{$\begin{array}{l}\text { Load } \\
(\mathrm{kW})\end{array}$} & \multicolumn{10}{|c|}{ Fuel } \\
\hline & & B0 & SB 5 & BT 5 & SB 20 & BT 20 & SB 50 & BT 50 & SB 100 & BT 100 & $\mathrm{LA}^{\mathrm{b}}$ \\
\hline \multirow{4}{*}{$\begin{array}{l}\mathrm{MC} \\
(\mathrm{g} / \mathrm{s})\end{array}$} & 0.5 & 0.2 & 0.3 & 0.3 & 0.2 & 0.2 & 0.2 & 0.2 & 0.3 & 0.2 & $0.2 \mathrm{a}$ \\
\hline & 1.0 & 0.2 & 0.3 & 0.2 & 0.3 & 0.2 & 0.3 & 0.3 & 0.2 & 0.3 & $0.3 \mathrm{a}$ \\
\hline & 1.5 & 0.2 & 0.3 & 0.3 & 0.3 & 0.2 & 0.3 & 0.3 & 0.3 & 0.3 & $0.3 \mathrm{a}$ \\
\hline & $\mathrm{AVG}^{\mathrm{c}}$ & $0.2 \mathrm{a}$ & $0.3 \mathrm{a}$ & $0.3 \mathrm{a}$ & $0.3 \mathrm{a}$ & $0.2 \mathrm{a}$ & $0.3 \mathrm{a}$ & $0.3 \mathrm{a}$ & $0.3 \mathrm{a}$ & $0.3 \mathrm{a}$ & \\
\hline \multirow{7}{*}{$\begin{array}{c}\text { BSFC } \\
(\mathrm{g} / \mathrm{kWh})\end{array}$} & & 2282.3 & 2847.2 & 2444.5 & 2209.3 & 2009.3 & 2315.0 & 1990.0 & 2602.3 & 1943.1 & \\
\hline & 0.5 & \pm 196.3 & \pm 772.7 & \pm 94.3 & \pm 105.6 & \pm 18.3 & \pm 325.4 & \pm 196.7 & \pm 325.8 & \pm 112.5 & $2293.7 \mathrm{a}$ \\
\hline & 10 & 1079.4 & 1177.5 & 1026.8 & 1091.9 & 931.7 & 1080.7 & 1083.3 & 1070.8 & 1066.0 & \\
\hline & 1.0 & \pm 9.9 & \pm 72.0 & \pm 19.3 & \pm 111.4 & \pm 6.0 & \pm 71.5 & \pm 31.4 & \pm 48.8 & \pm 207.9 & $1067.6 b$ \\
\hline & 15 & 688.5 & 750.3 & 679.0 & 767.5 & 728.6 & 720.9 & 697.3 & 691.9 & 708.4 & \\
\hline & 1.5 & \pm 15.6 & \pm 28.6 & \pm 3.8 & \pm 140.0 & \pm 114.3 & \pm 37.4 & \pm 60.3 & \pm 45.9 & \pm 47.8 & 714./c \\
\hline & AVG & $1350.1 \mathrm{a}$ & $1591.7 \mathrm{a}$ & $1383.4 \mathrm{a}$ & $1356.2 \mathrm{a}$ & $1223.2 \mathrm{a}$ & $1372.2 \mathrm{a}$ & $1256.9 \mathrm{a}$ & $1454.9 \mathrm{a}$ & $1239.2 \mathrm{a}$ & \\
\hline \multirow{5}{*}{$\begin{array}{l}\mathrm{E} \\
(\%)\end{array}$} & 0.5 & $\begin{array}{c}3.8 \\
\pm 0.3\end{array}$ & $\begin{array}{c}3.2 \\
\pm 0.9\end{array}$ & $\begin{array}{c}3.5 \\
\pm 0.1\end{array}$ & $\begin{array}{c}4.1 \\
\pm 0.2\end{array}$ & $\begin{array}{c}4.4 \\
\pm 0.0\end{array}$ & $\begin{array}{c}4.1 \\
\pm 0.6\end{array}$ & $\begin{array}{c}4.7 \\
\pm 0.5\end{array}$ & $\begin{array}{c}3.9 \\
\pm 0.5\end{array}$ & $\begin{array}{c}5.1 \\
\pm 0.3\end{array}$ & $4.1 \mathrm{c}$ \\
\hline & 1.0 & $\begin{array}{c}8.0 \\
\pm 0.1\end{array}$ & $\begin{array}{c}7.4 \\
\pm 0.5\end{array}$ & $\begin{array}{c}8.4 \\
\pm 0.2\end{array}$ & $\begin{array}{c}8.3 \\
\pm 0.8\end{array}$ & $\begin{array}{c}9.5 \\
\pm 0.1\end{array}$ & $\begin{array}{c}8.6 \\
\pm 0.6\end{array}$ & $\begin{array}{c}8.6 \\
\pm 0.3\end{array}$ & $\begin{array}{c}9.3 \\
\pm 0.4\end{array}$ & $\begin{array}{c}9.5 \\
\pm 1.9\end{array}$ & $8.6 b$ \\
\hline & & 12.6 & 11.6 & 12.7 & 11.9 & 12.3 & 12.9 & 13.4 & 14.4 & 14.0 & \\
\hline & 1.5 & \pm 0.3 & \pm 0.4 & \pm 0.1 & \pm 2.2 & \pm 1.9 & \pm 0.7 & \pm 1.2 & \pm 1.0 & \pm 0.1 & $12.9 \mathrm{a}$ \\
\hline & AVG & $8.1 \mathrm{ab}$ & $7.4 \mathrm{~b}$ & $8.2 \mathrm{ab}$ & $8.1 \mathrm{ab}$ & $8.8 \mathrm{ab}$ & $8.5 \mathrm{ab}$ & $8.9 \mathrm{ab}$ & $9.2 \mathrm{a}$ & $9.6 \mathrm{a}$ & \\
\hline
\end{tabular}

${ }^{a}$ The averages followed by the same letter are not statistically different from one another.

${ }^{b}$ LA: load average

c AVG: average 
Table 5. Inorganic gas emission (average values and standard deviation at $5 \%$ probability level) ${ }^{\mathrm{a}}$

\begin{tabular}{|c|c|c|c|c|c|c|c|c|c|c|c|}
\hline \multirow{2}{*}{ Parameters } & \multirow{2}{*}{$\begin{array}{l}\text { Load } \\
(\mathrm{kW})\end{array}$} & \multicolumn{10}{|c|}{ Fuel } \\
\hline & & B0 & SB 5 & BT 5 & SB 20 & BT 20 & SB 50 & BT 50 & SB 100 & BT 100 & $\mathrm{LA}^{\mathrm{b}}$ \\
\hline \multirow{4}{*}{$\mathrm{CO}(\mathrm{ppm})$} & 0.5 & $\begin{array}{l}1506.1 \\
\pm 282.2 \\
\end{array}$ & $\begin{array}{r}1809.7 \\
\pm 157.5 \\
\end{array}$ & $\begin{array}{c}2149.2 \\
\pm 155.9 \\
\end{array}$ & $\begin{array}{r}2104.0 \\
\pm 142.3 \\
\end{array}$ & $\begin{array}{r}1619.9 \\
\pm 212.2 \\
\end{array}$ & $\begin{array}{r}1780.5 \\
\pm 260.3 \\
\end{array}$ & $\begin{array}{c}800.0 \\
\pm 138.7 \\
\end{array}$ & $\begin{array}{c}788.0 \\
\pm 216.9 \\
\end{array}$ & $\begin{array}{c}533.4 \\
\pm 150.6 \\
\end{array}$ & $1454.5 \mathrm{a}$ \\
\hline & 1.0 & $\begin{array}{r}1252.3 \\
\pm 231.5 \\
\end{array}$ & $\begin{array}{r}1605,0 \\
\pm 170.9 \\
\end{array}$ & $\begin{array}{r}1415.5 \\
\pm 131.3 \\
\end{array}$ & $\begin{array}{r}1521.2 \\
\pm 208.3 \\
\end{array}$ & $\begin{array}{l}1073.1 \\
\pm 98.9 \\
\end{array}$ & $\begin{array}{r}1376.7 \\
\pm 238.2 \\
\end{array}$ & $\begin{array}{r}546.7 \\
\pm 171.3 \\
\end{array}$ & $\begin{array}{r}568.6 \\
\pm 169.8 \\
\end{array}$ & $\begin{array}{r}427.3 \\
\pm 98.9 \\
\end{array}$ & $1087.4 \mathrm{~b}$ \\
\hline & 1.5 & $\begin{array}{c}988.8 \\
\pm 274.1 \\
\end{array}$ & $\begin{array}{r}1189.2 \\
\pm 112.3 \\
\end{array}$ & $\begin{array}{l}1041.8 \\
\pm 56.0 \\
\end{array}$ & $\begin{array}{l}1043.9 \\
\pm 68.0 \\
\end{array}$ & $\begin{array}{r}672.9 \\
\pm 56.0 \\
\end{array}$ & $\begin{array}{c}920.1 \\
\pm 150.7 \\
\end{array}$ & $\begin{array}{r}442.6 \\
\pm 74.8 \\
\end{array}$ & $\begin{array}{c}530.0 \\
\pm 204.8 \\
\end{array}$ & $\begin{array}{r}334.7 \\
\pm 73.7 \\
\end{array}$ & $796.0 \mathrm{c}$ \\
\hline & $\mathrm{AVG}^{\mathrm{c}}$ & $1249.1 \mathrm{ab}$ & $1534.6 \mathrm{ab}$ & $1535.5 \mathrm{ab}$ & $1556.4 \mathrm{a}$ & $1122.0 \mathrm{~b}$ & $1359.1 \mathrm{ab}$ & $596.5 \mathrm{c}$ & $628.9 \mathrm{c}$ & $431.8 \mathrm{c}$ & \\
\hline \multirow{4}{*}{$\mathrm{SO}_{2}(\mathrm{ppm})$} & 0.5 & $\begin{array}{r}65.9 \\
\pm 6.3 \\
\end{array}$ & $\begin{array}{r}61.7 \\
\pm 6.0 \\
\end{array}$ & $\begin{array}{r}71.4 \\
\pm 5.3 \\
\end{array}$ & $\begin{array}{c}67.1 \\
\pm 2.4 \\
\end{array}$ & $\begin{array}{c}42.0 \\
\pm 10.2 \\
\end{array}$ & $\begin{array}{r}40.8 \\
\pm 6.1 \\
\end{array}$ & $\begin{array}{r}15.8 \\
\pm 2.8 \\
\end{array}$ & $\begin{array}{r}18.2 \\
\pm 6.8 \\
\end{array}$ & $\begin{array}{r}12.9 \\
\pm 1.2 \\
\end{array}$ & $44.0 \mathrm{a}$ \\
\hline & 1.0 & $\begin{array}{c}48.3 \\
\pm 6.3\end{array}$ & $\begin{array}{c}55.2 \\
\pm 4.7\end{array}$ & $\begin{array}{l}49.5 \\
\pm 1.9\end{array}$ & $\begin{array}{l}51.0 \\
\pm 0.5\end{array}$ & $\begin{array}{c}22.7 \\
\pm 0.6\end{array}$ & $\begin{array}{c}30.4 \\
\pm 3.0\end{array}$ & $\begin{array}{r}10.6 \\
\pm 2.1\end{array}$ & $\begin{array}{r}13.0 \\
\pm 2.0\end{array}$ & $\begin{array}{c}11.3 \\
\pm 0.7\end{array}$ & $32.4 \mathrm{~b}$ \\
\hline & 1.5 & $\begin{array}{r}42.6 \\
\pm 2.6 \\
\end{array}$ & $\begin{array}{c}46.2 \\
\pm 0.6 \\
\end{array}$ & $\begin{array}{r}31.8 \\
\pm 0.3 \\
\end{array}$ & $\begin{array}{r}23.8 \\
\pm 3.1 \\
\end{array}$ & $\begin{array}{r}12.9 \\
\pm 1.0 \\
\end{array}$ & $\begin{array}{r}14.8 \\
\pm 0.5 \\
\end{array}$ & $\begin{array}{c}6.2 \\
\pm 2.2 \\
\end{array}$ & $\begin{array}{c}8.6 \\
\pm 0.5 \\
\end{array}$ & $\begin{array}{r}10.0 \\
\pm 0.2\end{array}$ & $21.9 \mathrm{c}$ \\
\hline & AVG & $52.3 \mathrm{a}$ & $54.4 \mathrm{a}$ & $50.9 \mathrm{a}$ & $47.3 \mathrm{a}$ & $25.9 \mathrm{bc}$ & $28.7 \mathrm{~b}$ & $10.9 \mathrm{c}$ & $13.2 \mathrm{bc}$ & $11.4 \mathrm{c}$ & \\
\hline \multirow{4}{*}{$\mathrm{NO}_{\mathrm{x}}(\mathrm{ppm})$} & 0.5 & $\begin{array}{c}24.1 \\
\pm 5.3 \\
\end{array}$ & $\begin{array}{r}29.2 \\
\pm 2.5 \\
\end{array}$ & $\begin{array}{r}32.3 \\
\pm 2.2 \\
\end{array}$ & $\begin{array}{r}35.9 \\
\pm 1.2 \\
\end{array}$ & $\begin{array}{r}36.0 \\
\pm 4.9 \\
\end{array}$ & $\begin{array}{r}31.7 \\
\pm 1.6 \\
\end{array}$ & $\begin{array}{c}46.4 \\
\pm 10.7 \\
\end{array}$ & $\begin{array}{r}36.9 \\
\pm 3.8 \\
\end{array}$ & $\begin{array}{r}52.7 \\
\pm 6.7 \\
\end{array}$ & $36.1 \mathrm{c}$ \\
\hline & 1.0 & $\begin{array}{c}38.3 \\
\pm 13.4 \\
\end{array}$ & $\begin{array}{r}43.3 \\
\pm 4.8 \\
\end{array}$ & $\begin{array}{c}51.1 \\
\pm 9.8 \\
\end{array}$ & $\begin{array}{r}55.4 \\
\pm 9.3 \\
\end{array}$ & $\begin{array}{c}52.0 \\
\pm 15.7 \\
\end{array}$ & $\begin{array}{r}52.5 \\
\pm 9.4 \\
\end{array}$ & $\begin{array}{c}45.0 \\
\pm 12.9 \\
\end{array}$ & $\begin{array}{c}29.7 \\
\pm 13.1 \\
\end{array}$ & $\begin{array}{r}67.3 \\
\pm 6.5 \\
\end{array}$ & $48.3 \mathrm{~b}$ \\
\hline & 1.5 & $\begin{array}{c}91.1 \\
\pm 24.5\end{array}$ & $\begin{array}{c}86.1 \\
\pm 23.7\end{array}$ & $\begin{array}{c}92.1 \\
\pm 14.1\end{array}$ & $\begin{array}{c}93.5 \\
\pm 17.0\end{array}$ & $\begin{array}{c}94.1 \\
\pm 4.3\end{array}$ & $\begin{array}{c}65.7 \\
\pm 19.1\end{array}$ & $\begin{array}{c}77.7 \\
\pm 13.9\end{array}$ & $\begin{array}{c}88.4 \\
\pm 36.5\end{array}$ & $\begin{array}{r}88.6 \\
\pm 7.2\end{array}$ & $86.4 \mathrm{a}$ \\
\hline & AVG & $51.2 \mathrm{a}$ & $52.9 \mathrm{a}$ & $58.5 \mathrm{a}$ & $61.6 \mathrm{a}$ & $60.7 \mathrm{a}$ & $50.0 \mathrm{a}$ & $56.4 \mathrm{a}$ & $51.7 \mathrm{a}$ & $69.5 \mathrm{a}$ & \\
\hline \multirow{4}{*}{$\mathrm{O}_{2}(\%)$} & 0.5 & $\begin{array}{r}17.8 \\
\pm 0.7 \\
\end{array}$ & $\begin{array}{r}17.3 \\
\pm 0.5 \\
\end{array}$ & $\begin{array}{c}17.1 \\
\pm 0.4\end{array}$ & $\begin{array}{r}17.0 \\
\pm 0.1 \\
\end{array}$ & $\begin{array}{r}17.4 \\
\pm 0.5 \\
\end{array}$ & $\begin{array}{r}17.6 \\
\pm 0.7 \\
\end{array}$ & $\begin{array}{r}18.4 \\
\pm 0.5 \\
\end{array}$ & $\begin{array}{r}18.5 \\
\pm 0.6 \\
\end{array}$ & $\begin{array}{r}18.4 \\
\pm 0.7 \\
\end{array}$ & $17.7 \mathrm{a}$ \\
\hline & 1.0 & $\begin{array}{c}18.0 \\
\pm 0.7\end{array}$ & $\begin{array}{c}17.1 \\
\pm 0.7\end{array}$ & $\begin{array}{c}16.8 \\
\pm 0.6\end{array}$ & $\begin{array}{c}16.5 \\
\pm 0.6\end{array}$ & $\begin{array}{r}17.3 \\
\pm 0.5\end{array}$ & $\begin{array}{c}17.3 \\
\pm 0.8\end{array}$ & $\begin{array}{c}18.7 \\
\pm 0.5\end{array}$ & $\begin{array}{c}19.1 \\
\pm 0.6\end{array}$ & $\begin{array}{c}18.3 \\
\pm 0.6\end{array}$ & $17.7 \mathrm{a}$ \\
\hline & 1.5 & $\begin{array}{c}17.0 \\
\pm 0.4 \\
\end{array}$ & $\begin{array}{c}16.5 \\
\pm 0.6 \\
\end{array}$ & $\begin{array}{r}16.2 \\
\pm 0.5 \\
\end{array}$ & $\begin{array}{c}16.1 \\
\pm 0.5 \\
\end{array}$ & $\begin{array}{c}17.1 \\
\pm 0.4 \\
\end{array}$ & $\begin{array}{r}17.6 \\
\pm 0.7 \\
\end{array}$ & $\begin{array}{r}18.2 \\
\pm 0.5 \\
\end{array}$ & $\begin{array}{r}18.4 \\
\pm 1.1 \\
\end{array}$ & $\begin{array}{r}18.0 \\
\pm 0.5 \\
\end{array}$ & $17.2 \mathrm{~b}$ \\
\hline & AVG & $17.6 \mathrm{~b}$ & $17.0 \mathrm{cde}$ & $16.7 \mathrm{de}$ & $15.5 \mathrm{e}$ & $17.3 \mathrm{bcd}$ & $17.5 \mathrm{bc}$ & $18.4 \mathrm{a}$ & $18.6 \mathrm{a}$ & $18.2 \mathrm{a}$ & \\
\hline
\end{tabular}

${ }^{a}$ Averages followed by the same letter are not statistically different from one another.

${ }^{b}$ LA: load average

'AVG: average 
Table 6. BTEX emissions relative to pure diesel (SB0 or BT0)

\begin{tabular}{|c|c|c|c|c|c|}
\hline \multirow{2}{*}{ Fuel } & \multirow{2}{*}{ Load $(\mathrm{kW})$} & \multicolumn{4}{|c|}{ Difference relative to pure diesel $(\%)$} \\
\hline & & Benzene & Toluene & Ethylbenzene & Xylene \\
\hline SB 50 & 0.5 & $>100.0$ & +23.4 & -52.9 & -68.2 \\
\hline BT 50 & 0.5 & -29.4 & -39.5 & -77.7 & -75.9 \\
\hline SB 100 & 0.5 & +19.5 & -78.4 & -92.5 & -94.9 \\
\hline BT 100 & 0.5 & -82.9 & -92.7 & -96.4 & +98.0 \\
\hline SB 50 & 1.0 & +65.2 & +20.5 & +17.1 & +25.8 \\
\hline BT 50 & 1.0 & -59.0 & -48.9 & -65.2 & -31.8 \\
\hline SB 100 & 1.0 & -29.5 & -79.9 & -82.8 & -84.7 \\
\hline BT 100 & 1.0 & -72.5 & -90.3 & -91.9 & -90.0 \\
\hline SB 50 & 1.5 & $>100.0$ & +88.9 & +64.9 & +27.7 \\
\hline BT 50 & 1.5 & -20.5 & -39.8 & -71.5 & -57.4 \\
\hline SB 100 & 1.5 & $>100.0$ & -40.8 & -65.1 & -80.9 \\
\hline BT 100 & 1.5 & -27.3 & -72.4 & -80.6 & -88.9 \\
\hline
\end{tabular}




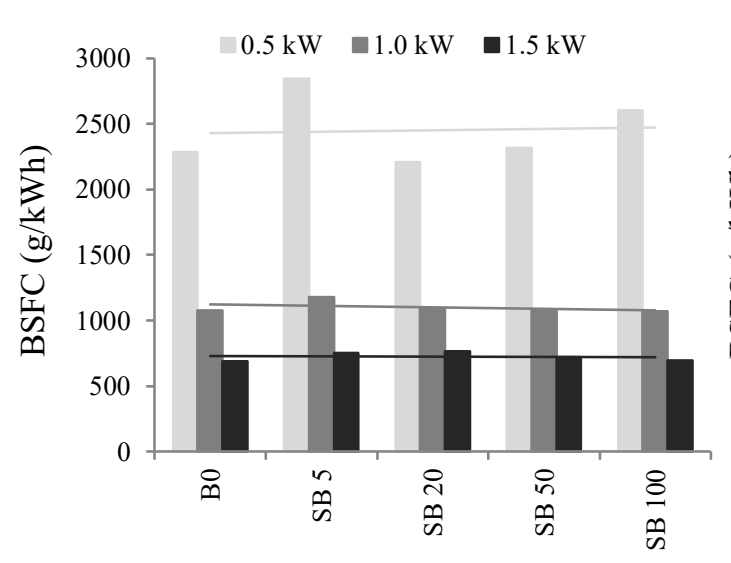

Fuel blend

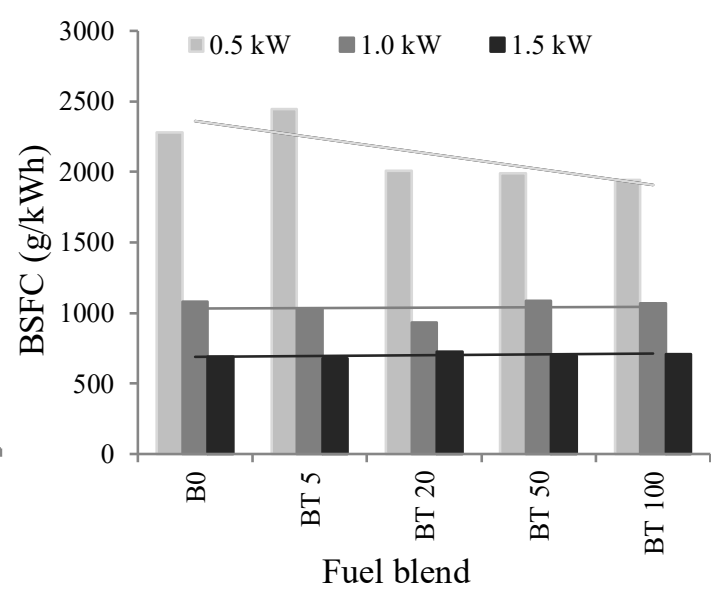

Fuel blend

Figure 1. Break specific fuel consumption (BSFC) as a function of fuel type, fuel blends and loads.
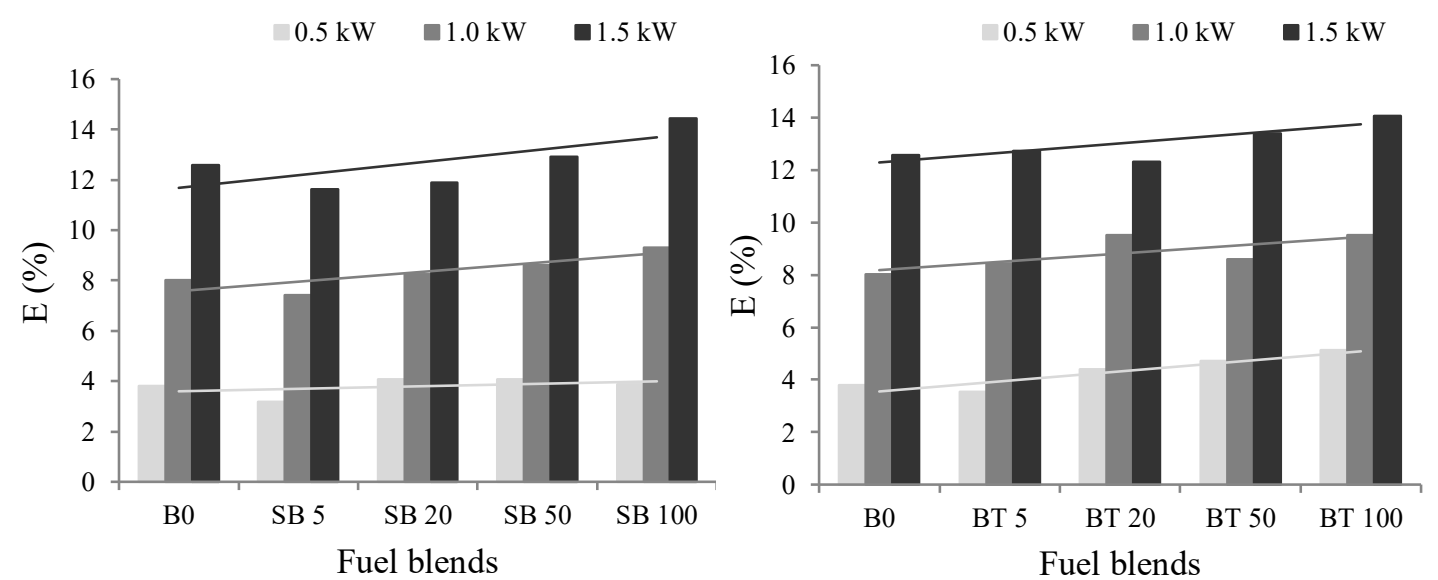

Figure 2. Overall efficiency (E) as a function of system load and fuel type and blends 

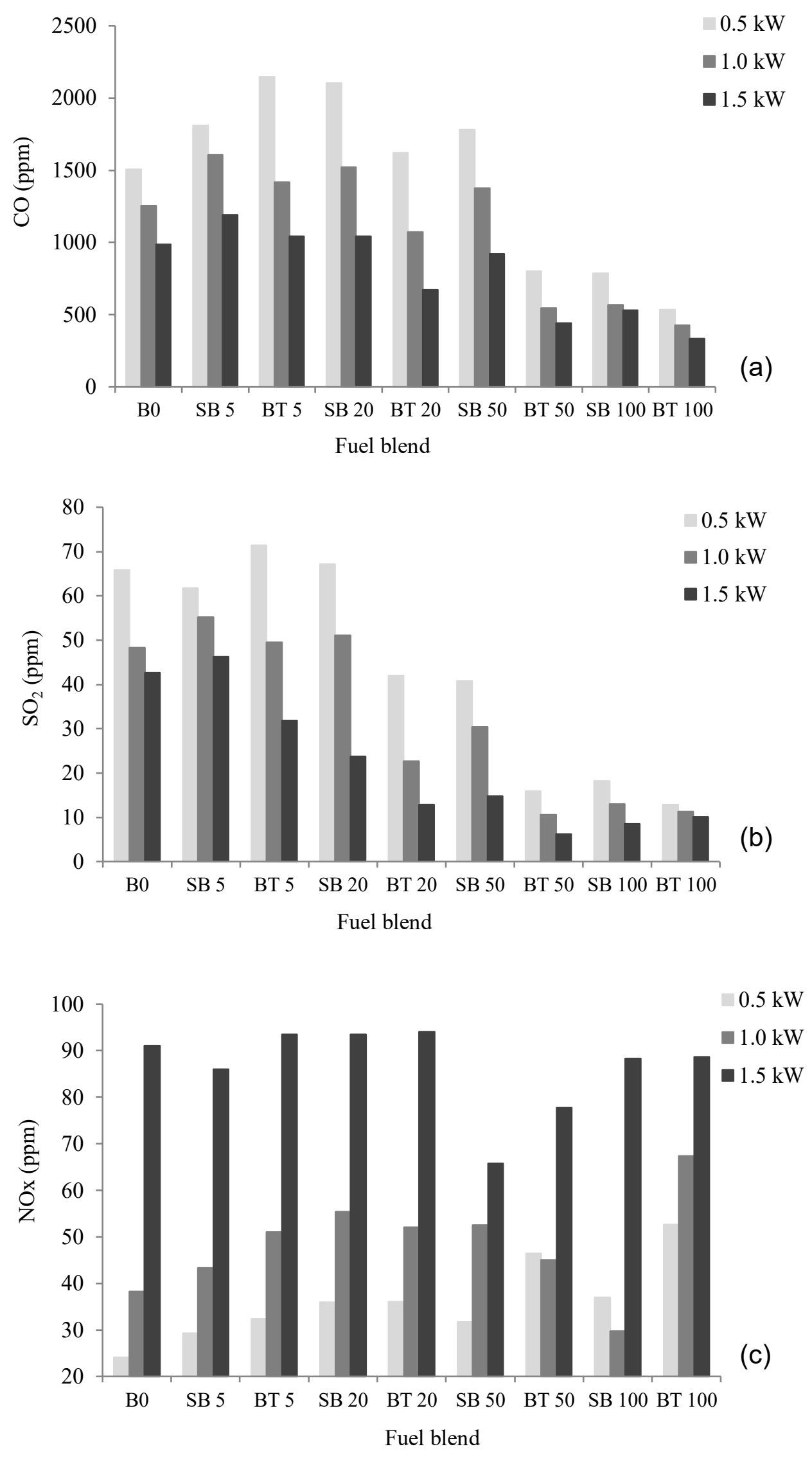

Figure 3. Inorganic gas emissions as a function of load, fuel type and blends. 


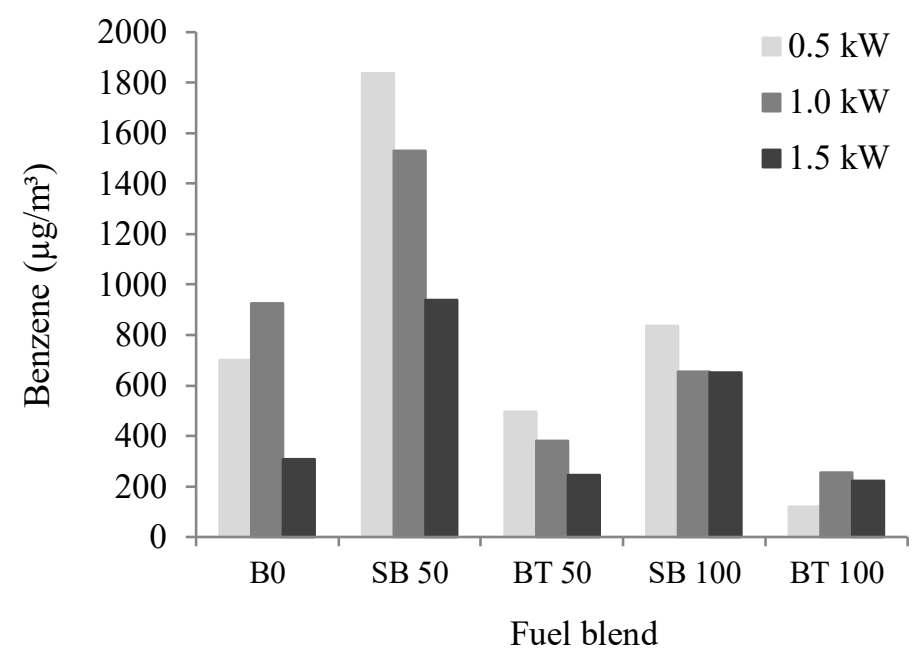

Figure 4. Benzene emissions with different fuels and loads evaluated.

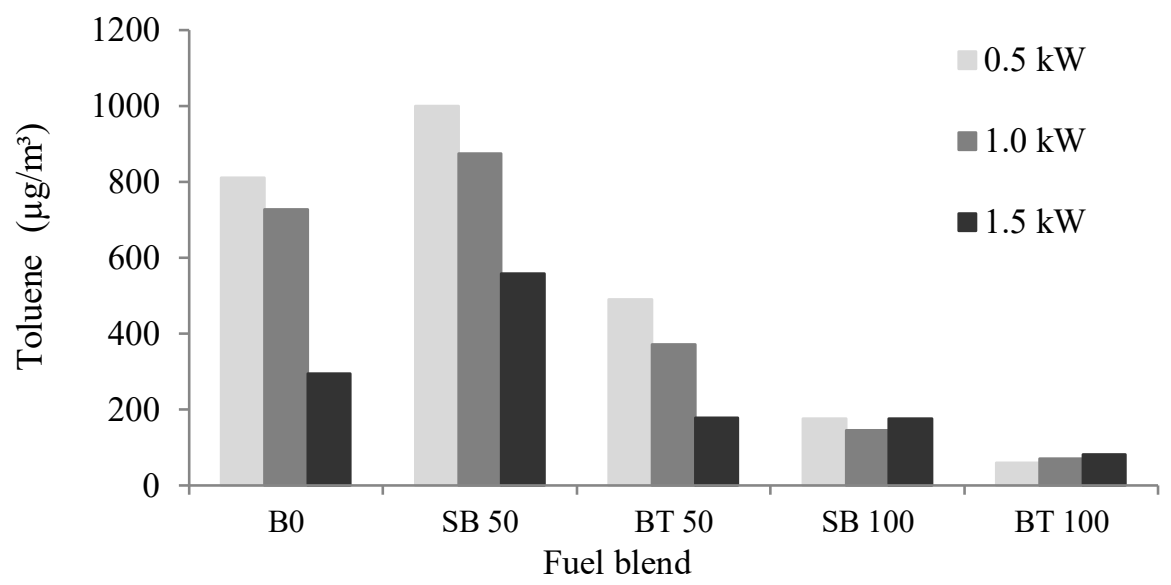

Figure 5. Toluene emissions with different fuels and loads evaluated. 


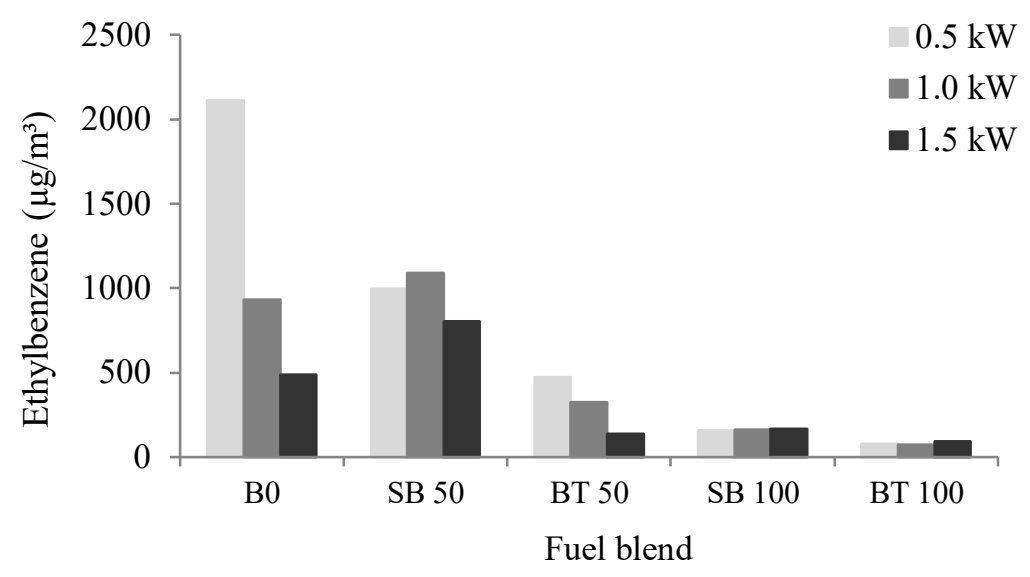

Figure 6. Ethylbenzene emissions with different fuels and loads evaluated.

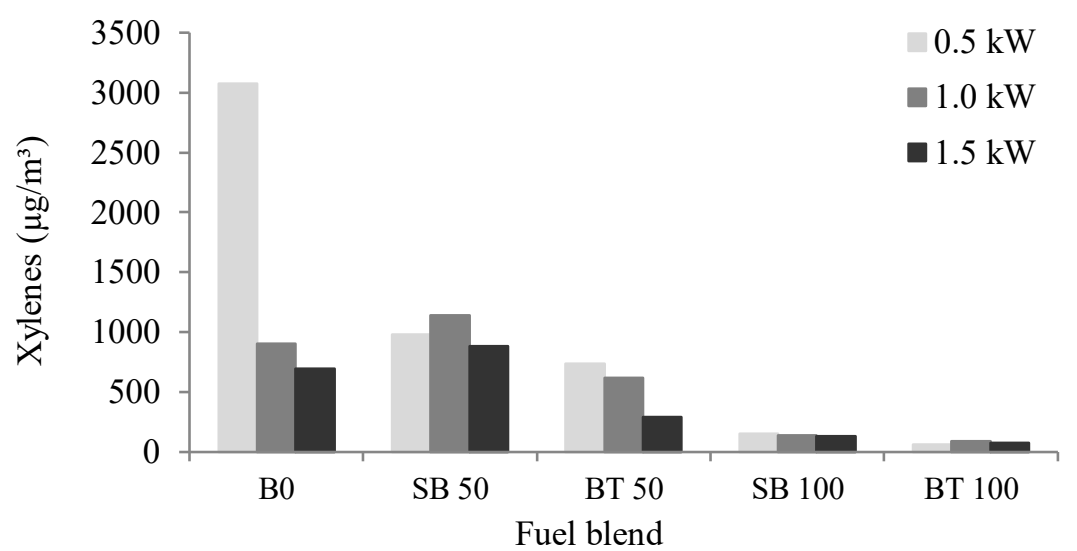

Figure 7. Xylenes emissions with different fuels and loads evaluated. 